\title{
Climate change adaptation, coffee, and corporate social responsibility: challenges and opportunities
}

\author{
Gino B. Bianco
}

\begin{abstract}
Climate change is making a profound impact on agricultural production across the globe. Coffee (especially the Arabica variety) is one of the most severely affected crops. Adaptive measures are therefore needed to ensure the industry's survival. Although large coffee companies have a long history of environmental action, less is known about their strategies and attitudes related to climate adaptation. This paper attempts understand how global coffee companies are addressing climate change adaptation as part of corporate social responsibility (CSR) strategies and what barriers may exist to prevent future scale-up. To answer this question, I analyzed overall global adaptation needs and the specific needs of the coffee industry, which revealed serious financial, capacity-related, and principle-based challenges. To better understand how the industry may view climate adaptation, I reviewed CSR theoretical literature and the history of CSR within the coffee industry. Through this analysis, I determined the promotion of climate adaptation in the coffee industry can best be explained by the "Creating shared value" (CSV) framework. Using the CSV framework and an understanding of global adaptation challenges, I reviewed the CSR strategies of five major coffee companies as well as supporting literature and industry information. I find that all five companies have expansive CSR programs, yet none seriously undertake climate adaptation efforts and/or make them public. I suggest several reasons for this absence, including competing CSR priorities, lack of awareness, competition, lack of leadership, the controversial nature of climate change, and the overemphasis of certification. I end the paper with a call for more collaboration and research around the adaptation issue for the coffee industry.
\end{abstract}

Keywords: Coffee, Climate change, Adaptation, Mitigation, Corporate social responsibility

\section{Introduction}

Climate change poses an existential threat to the global coffee industry. Increasing average temperatures, more frequent droughts and heat waves, and inclement weather patterns threaten to upend a large portion suitable coffee producing areas over the next 50 years (Davis, Gole, Baena, \& Moat, 2012; Rahn et al., 2018). This implies that large multinational coffee companies could lose substantial profits and even disappear entirely if climate trends continue unabated. Even if ambitious global emission reduction targets are met, the coffee industry could still face substantial losses. Given the severity of

Correspondence: Gbianco3387@gmail.com Somerville, USA

(c) The Author(s). 2020 Open Access This article is licensed under a Creative Commons Attribution 4.0 International License which permits use, sharing, adaptation, distribution and reproduction in any medium or format, as long as you give appropriate credit to the original author(s) and the source, provide a link to the Creative Commons licence, and indicate if changes were made. The images or other third party material in this article are included in the article's Creative Commons licence, unless indicated otherwise in a credit line to the material. If material is not included in the article's Creative Commons licence and your intended use is not permitted by statutory regulation or exceeds the permitted use, you will need to obtain permission directly from the copyright holder. To view a copy of this licence, visit http://creativecommons.org/licenses/by/4.0/. 
perspective, which is less discussed than climate mitigation and broader environmental activities. This research also contributes to discussions of CSR activities in developing country contexts.

The article is organized as follows: First, I provide an overview of the global coffee industry, followed by a review of the pertinent climate-related issues it faces and the evolution of coffee CSR strategies over time. Next, I propose a theoretical framework to understand how major coffee companies may be viewing the climate adaptation challenge. Armed with this framework, I scrutinize the overall CSR strategies of five major industry players with an eye toward climate adaptation. Finally, I offer possible explanations for the absence of climate adaptation in these strategies and suggest areas for future research.

\section{Background}

\section{The global coffee industry}

Coffee is one of the most widely traded and consumed commodities in the world. The demand for coffee is also growing (FAO, 2015A; Panhuysen \& Pierrot, 2018), perhaps due to increased demand from emerging economies. Despite its wide consumption in developed countries, coffee is overwhelmingly grown in less developed economies. In addition, it is estimated that $70 \%$ of the approximately 25 million coffee producers are smallholders who manage less than 10 ha of land (Panhuysen \& Pierrot, 2018; Rahn et al., 2018). This means that coffee production is potentially a source of economic development (FAO, 2015a; Rahn et al., 2018). Even though smallholders and developing economies produce most of the world's coffee, they reap few of the benefits. Global trade and sale of coffee is increasingly concentrated in a few "mega" companies housed mostly in the developed world (Panhuysen \& Pierrot, 2018).

Coffee production can be split into two types: Arabica (Coffea arabica) and Robusta (Coffea robusta). Robusta accounts for roughly $40 \%$ of global production and is generally grown in hotter climates, lower elevations, under less shade, and using more mechanized means of production, (FAO, 2015a). Robusta is also considered to be of poorer quality. Arabica accounts for the remaining $60 \%$ of global production and is the preferred coffee of choice for consumers in the United States and Europe (FAO, 2015a). Arabica is not as hardy as Robusta, requiring more shade, higher elevations, and cooler temperatures to thrive (FAO, 2015a; Rahn et al., 2018). Because of the nature of Arabica coffee, production cannot easily be mechanized and is much more labor intensive (Rahn et al., 2018). This may be why Arabica production has remained the domain of the smallholder for so long. This paper will focus mostly on Arabica production, since it is the variety of most concern to
Western companies and consumers, most threatened by climate change, and the most tied to rural development.

\section{Global climate change: the adaptation challenge}

Global climate change is already affecting both natural and human systems across the globe. The Food and Agriculture Organization of the United Nations (FAO) estimates that between 2003 and 2015, climate related events caused \$1.5 trillion in economic damages (FAO, 2015b). While some effects of global climate change will be positive (such as through prolonged growing seasons and warmer climates in Europe and North America), changes for economies near the tropics will mostly be negative, including longer and more frequent droughts, extreme weather events, and more severe heat waves (IPCC, 2014). Climate-related disruptions tend to exacerbate existing challenges for poor and marginalized populations (ibid.).

Recently, world governments have committed to keeping global climate change in check, pursuing efforts to mitigate greenhouse gas (GHG) emissions to keep warming to under 2 degrees Celsius pre-industrial levels (The Paris Agreement, 2016). Even if these ambitious efforts are successful, climate impacts will continue to occur, and will disproportionately effect populations with the fewest resources and capabilities to deal with them (IPCC, 2014). Recognizing this reality, the 2016 Paris Agreement also supports climate adaptation efforts by developing country national governments, developed country ("donor") governments, and international organizations.

The Intergovernmental Panel on Climate Change (IPCC) defines adaptation as "The process of adjustment to actual or expected climate and its effects. In human systems, adaptation seeks to moderate or avoid harm or exploit beneficial opportunities." (2014). Put another way, while climate mitigation is about halting future warming by reducing emissions and building carbon sinks, climate adaptation is about adjusting to the effects of warming that can and will take place, regardless of the success of mitigation efforts. A related yet distinct concept is climate "resilience", which can be thought of as the strength of a system to recover from shocks. In the context of climate change, adaptation can be thought of as the process of increasing or maintaining reliance of systems in response to or in anticipation of shocks (Nelson, 2011) (Table 1).

A useful way to understand the climate adaptation process and the options available to actors is through an analysis of climate-related risks. Climate risks are the combination of "exposure" (i.e., location, infrastructure, assets, ecosystems, etc.), "vulnerability" (i.e. the capacity to cope with changes) and "hazards" (the potential for climate related events) (IPCC, 2014). Actors interested 
Table 1 Definitions of and differences between climate adaptation and mitigation

\begin{tabular}{lll}
\hline & Climate Mitigation & Climate Adaptation \\
\hline Definition & $\begin{array}{l}\text { "A human intervention to reduce the sources } \\
\text { or enhance the sinks of greenhouse gases." } \\
\text { (IPCC, 2014). }\end{array}$ & $\begin{array}{l}\text { "The process of adjustment to actual or expected climate and } \\
\text { its effects. In human systems, adaptation seeks to moderate or } \\
\text { avoid harm or exploit beneficial opportunities" (IPCC, 2014). }\end{array}$ \\
$\begin{array}{l}\text { Reducing fossil fuels in favor of renewables, } \\
\text { conserving forests and other ecosystems, } \\
\text { energy, and fuel efficiency. }\end{array}$ & $\begin{array}{l}\text { Flood resistant buildings and cities, using more resilient crop } \\
\text { varieties, shifting production to different areas, migration. }\end{array}$ \\
Benefits & Global & Mostly local \\
Type of good & Mostly public & Mostly private \\
$\%$ of total climate finance & $>90 \%$ & $<10 \%$
\end{tabular}

in reducing climate-related risks thus have several options. For instance, they could use explicit adaptation measures to reduce vulnerability by introducing more climate resilient crop varieties or building flood resistant infrastructure. Another option is to reduce vulnerability by improving overall socio-economic development, increasing the population's resilience. Actors could also reduce exposure by promoting livelihood transitions from an industry that is more impacted by climate change to one that is less impacted. A more extreme example of reducing exposure might be the promotion of migration from a more to less climate-impacted area. Hazards are more difficult to address in the short-term since they depend on geography and exogenous factors such as global climate change caused by total emissions and possibly reduced through global mitigation efforts (IPCC, 2014). Actors thus have many options to reduce climate risks, though most of them require substantial investments beyond what is possible for many economies. Because of this, many economies and industries are turning to external sources of finance (Fig. 1).

\section{Climate finance for adaptation}

Despite the financial needs of developing countries and their higher vulnerability to climate change, donors and investors are reluctant to pay for adaptation efforts. Of all climate finance from public and private sources, only $7 \%$ is currently labelled as adaptation funding, with the rest supporting mitigation (Buchner et al., 2017). This is discouraging considering that total climate finance is reaching all-time highs, and because developing country representatives pushed for equal financing for adaptation and mitigation during the Paris Climate negotiations. Adaptation funding is dominated by national financial institutions and multilateral organizations (Micale, Tonkonogy, \&

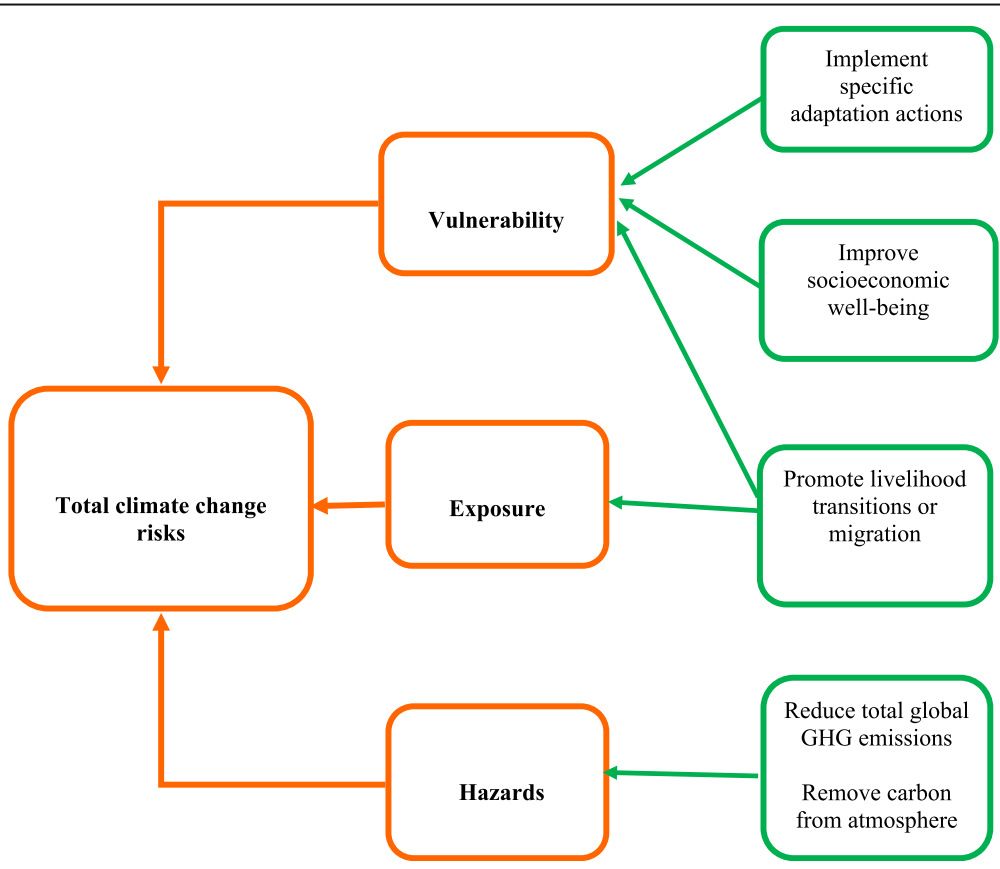

Fig. 1 Adaptation intervention pathways (adapted from IPCC, 2014 and simplified) 
Mazza, 2018) which are currently struggling to raise and disburse funds. Bilateral aid from donor governments and climate funds contributes to adaptation finance but makes up only a small percentage of their total climate portfolios (Lyster, 2017). In addition to the dearth of adaptation finance, roughly $80 \%$ of all climate finance remains in the country of origin (Buchner et al., 2017), suggesting that poorer countries are neglected. The reasons behind donors' and investors' reluctance to support adaptation can be split into two broad categories: principle-related and logistical and capacity-related:

\section{Principle-related barriers}

The benefits of climate mitigation are global; each ton of GHG avoided or sequestered benefits the global economy and humanity by reducing the potential warming of the entire planet (Klein, Schipper, \& Dessai, 2005; Lecocq et al. 2011). Adaptation on the other hand is mostly a local good. Each country, province, state, municipality, and city-and the different economies and businesses within them-have different adaptation needs. For instance, an adaptation investment in one city will not directly benefit stakeholders in another city. This means that an investment in adaptation is harder to justify from the perspective of a developed "donor" country, since the investment does not benefit the donor in a direct way. A related difference is that mitigation benefits are mostly "public goods", while adaptation benefits are mostly "private goods". Mitigation is also much easier to quantify than adaptation (Klein et al., 2005; Lecocq et al. 2011). For example, many economists and scientists have developed models for determining the "social cost of carbon" to the global economy. However, the quantifiable benefits of adaptation are much more elusive (Stanton, 2011). For government donors, adaptation may be a more difficult sell to taxpayers because it is seen as "giving up" on trying to reduce climate impacts (mitigation) by accepting the need to adapt (see for example Wood, 2019 or Ostrander, 2013).

\section{Logistical and capacity-related barriers}

Logistical and capacity-related barriers to adaptation finance are probably more concerning for private investors. Since adaptation benefits are harder to quantify (Klein et al., 2005), they are also harder to track progress on. This makes performance monitoring challenging for investors. Furthermore, there is lack of consensus on what counts as adaptation finance, how to differentiate it from other types of development finance, and how to measure it. Other barriers include nascent development of adaptation-related products and services, lack of scalability of these products and services, and factors specific to the local market context (Micale et al., 2018).
As a result of both principle and logistical and capacity constraints, adaptation is often neglected by international donors and investors and even by governments most affected by climate damages (OECD, 2012). Given the strain on international governments because of the financial crisis, global health crisis, security concerns such as international migration and terrorism, and the commitments to climate mitigation, new strategies and actors must be identified to meet the adaptation gap (Ostrom, 2008 OECD, 2012).

\section{Coffee production: adaptation needs and challenges}

The need for climate adaptation is particularly relevant to the coffee industry. As the natural climate system is disrupted, production of coffee is becoming increasing difficult, especially for the less hardy Arabica variety. Arabica crops, which thrive at higher altitudes and mild temperatures, are extremely sensitive to changes in average temperatures, as well as changes in rainfall patterns, soil quality, and unseasonal frosts (Davis et al., 2012; Rahn et al., 2018). Even in a world without significant global climate change, Arabica coffee can only be grown in specific agro-ecological zones. Unfortunately, increasing global concentrations of $\mathrm{CO} 2$ are disrupting these zones by raising average temperatures, disrupting rainfall patters, more common and severe extreme weather events, and broadening the vectors for diseases and pests (IPCC, 2014.) A recent biophysical projection of climate impacts on Arabica coffee in Ethiopia suggest that if current climate trends continue, by 2080 somewhere between $65 \%$ and almost $100 \%$ of current coffee-growing areas will be unsuitable for production (Davis et al., 2012). Another analysis of coffee-growing areas in Nicaragua finds that by 2050 more than $90 \%$ of the current growing areas will be unsuitable for production (Laderach et al., 2017).

These are disturbing statistics for coffee drinkers and the global coffee industry; they are even more frightening to coffee farmers whose livelihoods and local economies depend on its production. Since most coffee producers are smallholders, they often have less capacity to address climatic changes and shocks (Laderach et al., 2017; Panhuysen \& Pierrot, 2018). Even in a scenario where the international community manages to meet the Paris Climate Agreement targets, the global production of coffee and the millions of smallholders who depend on it will face serious adaptation challenges. At the same time, global demand for coffee is increasing. Since 2010, global demand increased by $20 \%$, and is not slowing down (Panhuysen \& Pierrot, 2018). Thus, the global coffee industry and coffee producers have a shared interest in large-scale adaptation to climate change if either one is to survive through the twenty-first century. 
There are several tools which could be deployed to reduce the climate risks for smallholder coffee farmers. For instance, specific adaptive measures could be scaled up to reduce climate vulnerability. These include increased shade cover, introducing climate resistant coffee varieties, restoration and rehabilitation of degraded areas, improved soil and water management, integrated pest management, and insurance and other risk sharing schemes (Cohn et al., 2017; Davis et al., 2012; Laderach et al., 2017). Another strategy is to reduce exposure to climate risks by helping farmers transition from coffee to the production of other crops which thrive in warmer climates, such as cocoa (Laderach et al., 2017). While these types of transitions reduce climate risks for farmers, they do nothing to help coffee companies meet increasing demand. Another strategy is to increase the overall socio-economic development of smallholders, thereby reducing their exposure and vulnerability (IPCC, 2014). This final strategy is perhaps the most commonly used by individual coffee companies through CSR activities, though usually not explicitly for the purpose of adaptation. This strategy is also problematic because it assumes coffee farmers will recognize and make the needed climate adaptations given enough resources, ignoring possible technical and educational gaps. The following section will explore these CSR efforts to date in more detail to understand the reasoning and strategy behind them.

\section{Corporate social responsibly (CSR) in the coffee industry}

CSR campaigns from large multinationals are deeprooted in the coffee industry, dating back to at least the 1990s. Some coffee scholars point to the collapse of the International Coffee Organization regime in 1989 as the start of the increased CSR interest in coffee. The end of the International Coffee Organization signified a transfer of power in the coffee industry from the developing exporting countries, to the large multinational coffee companies (Daviron \& Ponte, 2005; Kolk, 2005; Talbot, 2004). At around the same time, oversupply of coffee in global markets led to falling prices for producers and eventually to worsening social and environmental conditions for farmers (Hamann, Luschnat, Niemuth, Smolarz, \& Golombek, 2014). This led to increased interest from consumers, and philanthropic and development organizations to improve the lives of farmers in the value chain, and increased pressure on global coffee companies (Millard, 2017).

While some NGO efforts were successful in increasing consumer awareness about the plight of coffee farmers and the environment, they lacked coordination and the impact was generally small (Millard, 2017). If transformational change were to happen, it would need to come from the new de facto leaders of the industry: the multinational corporations (Kolk, 2005). The 1990s and early 2000s saw a rapid expansion of independent certification schemes for coffee producers, which were quickly adopted by large coffee companies to protect their brand image and respond to consumer pressure (Daviron \& Ponte, 2005; Millard, 2017). These certification standards included FairTrade, Organic, 4C, Utz, and Rainforest Alliance, and focused on issues such as decent pay, pesticide application, child labor, protective gear use, deforestation, biodiversity management, waste disposal and water management, among others (Samper \& Quiñones-Ruiz, 2017). These certification systems for responsibly produced coffee expanded so quickly that all major international coffee firms had adopted sustainability initiatives by the 2000 s. Today, $40 \%$ of all coffee produced globally now meets one or more standards (Levy, Reinecke, \& Manning, 2016). In addition, some firms such as Starbucks developed their own in-house certification standard, based on the best practices from key third-party schemes (Millard, 2017).

While these were positive trends, several authors have challenged the apparent "paradox" of the coffee industry (Daviron \& Ponte, 2005; Levy, Reinecke, \& Manning, 2016; Samper \& Quiñones-Ruiz, 2017). If so much of the global coffee supply chain is produced in an environmentally and socially responsible way, why are smallholder farmers still struggling? One possible answer to the paradox is that large coffee companies are not responding to the root causes of smallholder poverty (see for example Escobar Botero, Arboleda Diaz, Marín Cadavid, \& Muhss, 2011; Glasbergen, 2018). They may be responding to consumer demands and peer pressure from firms in the same industry, but this does not always address key environmental and livelihood challenges that smallholders face (ibid.). The issue of climate change is a prime example. Given the current and future changes to growing conditions for coffee farmers, one would expect climate adaptation to be a more explicit concern to coffee companies interested in their image and the longterm viability of their supply chains. On a superficial level, this appears not to be the case.

The broad concept of climate change itself is a relatively new addition to the CSR messaging of global coffee companies, with the first large initiative launched only in 2010 (Millard, 2017). Additional multistakeholder programs have since emerged to address climate adaptation in the coffee value chain. However, these include few of the large industry players, and are driven typically by NGOs and governmental organizations. Climate adaptation still appears rather low on the list of the CSR objectives for companies themselves. For example, although "climate change" is one of the most 
reported indicators used by British coffee companies in 2018 (Bradley \& Botchway, 2018), they still predominantly emphasize mitigation. The following sections will explore how large companies talk about and implement climate adaptation strategies as part of larger CSR initiatives in an attempt to understand if an "adaptation gap" really exists, how serious it is, and why it persists.

\section{Research methods \& theoretical framework}

\section{Literature review and theoretical framework}

Before examining the presence or absence of adaptation actions within coffee CSR initiatives, it is important to ground the findings in theories behind the pursuit of CSR. CSR is broadly defined as "A company's sense of responsibility towards the community and environment (both ecological and social) in which it operates." (Business Dictionary, 2019). The European Commission provides a shorter definition as "the impact of business on society". (The European Commission Corporate Social Responsibility \& Responsible Business Conduct, 2019). A.B. Carroll explains that the idea of CSR is a relatively new one. Although prominent business thinkers did hint at the idea of CSR as early as the 1950s, it was not until the 1980s and 1990s that the term really became part of mainstream thought in the industry (Carroll, 2001). Interestingly, the emergence of CSR as a concept roughly maps to the rise of the environmental movement in the developed world. Given how new CSR is as a concept, it is not surprising that climate change is just entering its lexicon in the past decade. Climate change itself is also a relatively recent development in the public consciousness. The need for large-scale climate change adaptation is even more recent, which may further explain the delay.

A company theoretically would employ a CSR strategy for various reasons. Campbell links the health of economy and of the corporation itself as strong predictors of CSR behavior (Campbell, 2007). This theory is also supported by a qualitative and quantitative analysis conducted by the Economist Business Unit (2008). Therefore, it is not surprising that the largest and most profitable coffee companies were behind the sustainable coffee movement during the late 1980s and 1990s when the global economy was strong. Campbell also finds that corporations are more likely to pursue CSR strategies as they meet "NGOs and other independent organizations that monitor them" among other factors (ibid.). In this sense, the pressure from environmental watchdogs and certification groups no doubt contributed to the development of CSR policies of coffee companies during the late 1980s and 1990s.

As I have explained, the CSR policies of coffee companies are not always environmental in nature. In fact, many corporations focused on workers' pay and child labor as the primary issues of concern (Kolk, 2011; Talbot, 2004). Environmental CSR, or "Corporate Ecological Responsibility" focuses on "mitigating a firm's impact on the natural environment" (Bansal \& Roth, 2000). According to Bansal and Roth, a corporation will "gogreen" for three primary reasons: competitiveness, legitimization, and social/ecological responsibility. According to these authors, firms who are motivated by competitiveness are more likely to engage in developing and marketing "green products". Companies that are motivated by legitimization are likely to be concerned with regulatory compliance, and engagement with environmental interest groups. Finally, companies motivated by social/environmental responsibility are likely to engage in donations to environmental causes, life-cycle analyses (LCAs) and unpublished initiatives. Using this lens, it appears that large coffee companies are mostly motivated by competitiveness ("green" marketing) and legitimation (in the form of certification requirements and collaboration with environmental groups). This framework helps us understand why a company would pursue strategies in favor of climate change mitigation (Bansal and Roth even use the word "mitigation" in their definition), but it does not explain the inclusion or exclusion of adaptation. For large coffee companies, the motivation for pursuing adaptation initiatives would be more existential.

The concept of climate adaptation as an existential need for companies and farmers alike is perhaps best encompassed by Porter and Kramer, in their seminal paper "Creating Shared Value" (CSV) (Porter \& Kramer, 2011). According to the authors, "shared value" is, "policies and operating practices that enhance the competitiveness of a company while simultaneously advancing the economic and social conditions in the communities in which it operates. Shared value creation focuses on identifying and expanding the connections between societal and economic progress". The authors further explain the concept as "expanding the total pool of economic and social value". Porter and Kramer use the relevant example of FairTrade, which they claim is merely a redistribution of resources and does not increase the total pool of resources available to the company, the farmer, and society.

The CSV frame so far seems the most relevant to describing the tendency of companies to support climate adaptation initiatives, since adaptation does not fit neatly into the boxes of competitiveness, legitimization, and social/ecological responsibility proposed by Bansal and Roth. Adaptation also goes beyond theories proposed by Campbell regarding the economic relationship between CSR and overall performance. The CSV lens is not perfect, however (see for example, Crane, Palazzo, Spence, 
\& Matten, 2014), but it does provide a workable framework to assess CSR in the coffee industry.

As coffee is mostly grown in developing countries, another relevant subsection of the literature is related to CSR practices in these countries by multinational corporations. Carroll, in an update to his influential 1999 paper, noted that CSR is growing in developing regions, owing to more companies viewing CSR as an important business strategy (2016). Latapi Agudelo, Johannsdottir, and Davidsdottir (2019) suggest the growth of CSR in developing countries can be attributed to new international frameworks and agreements, such as the Sustainable Development Goals (SDGs) and the Paris Climate Agreement. Visser (2009) suggests that CSR initiatives in developing countries are often distinct from those of developed countries and can present trade-offs between the concerns of shareholder and consumers and stakeholders in the countries where they operate. Several studies reinforce this disconnect between CSR priorities (Barkemeyer, 2011; Brown \& Knudsen, 2012), with some calling for more serious alignment with poverty alleviation targets (Idemudia, 2014; Ragodoo, 2009). Visser makes a related point, that only large countries with "very serious public images" are involved in CSR within developing countries (2008). This may suggest that if any coffee companies are engaging in CSR around climate adaptation, they would likely be large multinationals.

The following section will explore how several coffee companies are specifically tackling the issue climate adaptation, and how well it is explained by the CSV framework. In addition, it will attempt to frame these strategies within the context of CSR in developing countries.

\section{Research methods}

Armed with an understanding of CSR practices of coffee companies (especially through the CSV lens), the next step was to understand how the coffee industry is or is not strategically addressing climate adaptation at the producer level. To understand this question, I first created a list of the largest companies involved in the coffee supply chain based on volume of coffee sold (from Panhuysen \& Pierrot, 2018). I focused on large companies because of the observation of Campbell that the health of a company is a strong predictor of CSR (2007) and because they were more likely to have CSR information publicly available. This list of large companies included both roasters and retailers, and companies that are involved in both activities. I selected from this list a total of five companies, seeking a balance between roasters, retailers, and hybrids, as well as a balance between European and North American companies to control for possible corporate culture differences. Based on Visser's conclusion that only companies with exceptionally large public images would engage in CSR activities in developing countries (2008), I excluded large coffee companies such as JDE with less recognizable public images. I also excluded large traders such as Ecom for the same reason. Although traders are important industry actors, they operate more outside of the public view.

Once the companies were selected, I analyzed their public reports and communications, especially CSR related reports over the past 5 years. To supplement this research, I searched an academic database for peerreviewed and grey literature published in the past 10 years related to the company in question. The search terms included "[company name]" + "CSR" or "climate change", or "adaptation". Finally, I searched for broader industry-wide analyses related to adaptation and CSR published over the past 10 years using search terms "coffee", "CSR", "adaptation", and "climate change".

\section{Results}

\section{Industry trends}

Coffee companies appear to include a wide range of issues within their individual CSR strategies. One analysis of British coffee companies identified a total of 94 distinct sustainability indicators. Of these, 44 were environmental, 30 were social and 20 were economic in nature (Bradley \& Botchway, 2018). The authors found that the most reported indicators were related to climate change, though companies generally preferred to report on specific environmental issues affecting the farmers in their value chain, as opposed to global issues. Even though coffee companies appear concerned with several sustainability issues, there is clear skepticism about the effectiveness of this approach in generating true shared value. A 2018 Hivos commissioned report concluded that continued demand for coffee has not translated into the livelihood gains for farmers, who "remain largely voiceless in the discussions about a sustainable coffee sector" (Panhuysen \& Pierrot, 2018). Other reports are critical of the metrics used by companies to report on sustainability, which to date remain rooted in a set of certification standards which do not always encompass the whole picture or measure livelihoods of farmers properly (Levy et al., 2016; Millard, 2017). Yet another report suggests that CSR process could be improved through more equitable consensus between farmers and coffee companies to define metrics (Samper \& Quiñones-Ruiz, 2017). These analyses seem to suggest a shift is needed away from traditional CSR measures, toward one which better incorporates the needs and voices of producers. Implicitly this suggests a need to shift toward CSV.

\section{Tim Horton's}

A Canadian company in operation since 1964, Tim Horton's serves coffee and fast food in over 4000 locations 
worldwide. Tim Horton's CSR initiatives focus on community-building in areas where stores and offices are located, as well as "Coffee Partnerships" with communities which the company sources from in Central and South America (Tim Horton's, 2015). The Coffee Partnerships focus on social, environmental, and economic pillars, with each pillar consisting of technical assistance and training. The environmental pillar of these projects is holistic but does not directly address climate adaptation as a strategy, instead focusing on reducing biodiversity loss and limiting pollution to water and soil resources. Furthermore, the key performance measurements used by Tim Horton's in its recent GRI report center almost exclusively on climate mitigation targets, such as GHG emissions and energy usage. The phrase "climate change" is not used once in the report. Nevertheless, the idea of community partnerships it establishes in the coffee-sourcing regions is evidence of an attempt at CSV, rather than redistribution strategies.

\section{Dunkin' donuts}

Like Tim Horton's, Dunkin' Donuts specializes in coffee and fast food. The US-based company is much larger however, with over 10,000 stores, mostly in the United States. Dunkin' sources coffee that is both Rainforest Alliance and FairTrade Certified, though this appears to be a relatively small fraction of total coffee sold. One of the key metric categories in its CSR report is "Responsible Sourcing". However, it focuses on pulp and paper, palm oil and eggs, not coffee. The "Climate and Energy" section is mostly concerned with energy usage and reducing GHGs. Interestingly, coffee sourcing is not part of Dunkin's CSR metrics at all (Dunkin' Donuts, 2017). The company did however report a grant to Rainforest Alliance to provide technical assistance to farmers in Peru. It appears that climate adaptation is even less of a priority to Dunkin' than to Tim Horton's, yet the partnership with Rainforest Alliance indirectly addresses the issue. This finding may suggest that some companies see third-party certification as a means to "check the box" of environmental and climate-related CSR.

\section{Tchibo}

Tchibo is German coffee company of comparable size to Tom Horton's and Dunkin' Donuts. Tchibo's goal since 2006 has been to become a 100\% sustainable business. The company's 2018 sustainability report claims that Tchibo believes in sustainability "Because we believe that our future business success depends on a sustainable business policy", (Tchibo, 2018), which is the closest I have encountered to a "survival" type CSR message from a coffee company. Like the previous two companies, Tchibo is also concerned with its carbon footprint, highlighting it as one of its key performance metrics.
The company is also concerned with sustainable sourcing, dedicating a key performance metric to it as well. Unlike the previous two companies, support to coffee farmers is more front and center. In addition, Tchibo explicitly mentions climate change as a threat to the future of the industry and outlines specific actions to help farmers adapt. Tchibo seems at least on paper to embrace the concept of CSV as it relates to climate adaptation.

\section{Starbucks}

An American coffee company with over 28,000 locations around the world, Starbucks is a leader in the retail and coffeehouse industry. Starbucks was one of the first companies to popularize high-quality coffee consumption and "café culture" (Daviron \& Ponte, 2005). Perhaps as a result of this, Starbucks was one of the first coffee companies to embrace sustainability concerns, dating back at least as early as their engagement with the Environmental Defense Fund (EDF) and Conservation International (CI) in the late 1990s (Austin \& Reavis, 2004). Starbucks is committed to $100 \%$ ethical coffee sourcing, achieving 99\% as of 2018 (Starbucks, 2018). Unlike other coffee companies mentioned, Starbucks does not rely on third party certification, instead using its own in-house "C.A.F.E" standards. Starbucks also has several community-related CSR targets, such as education support for its workers. Although Starbucks does not explicitly mention adaptation or resilience in its annual CSR report, it does point to two programs which indirectly address the issue. The first is the Farmer Loan Program, which provided low-interest finance to farmers in their supply chain to make changes. The other is a tree donation program, which aims to donate 100 million "resilient" trees to farmers by 2025 (Starbucks, 2019). It is also relevant to note that Starbucks is part of CERES' Business for Innovative Climate and Energy Policy (BICEP) network, as well as a signee of the 2015 "Pledge" by major US companies to address climate change (White House Office of the Press Secretary, 2015). Clearly, Starbucks at least recognizes the importance of addressing climate change. These programs demonstrate a commitment to sustainability on the part of Starbucks, and even tangentially address the adaptation challenges, but do not explicitly address CSV as related to adaptation.

\section{Nestlé}

Nestlé is a Swiss company which includes coffee-related products Nespresso and Nescafé. Nestlé is the largest food and beverage company in the world and by far the oldest company I analyzed by close to a century. More than the other four companies mentioned, Nestlé embraces the concept of CSV, even going so far as to name their CSR report "Creating Shared Value" (Nestlé, 
2018). Interestingly, climate adaptation and resilience are also more front and center than for the other companies I analyzed. Nestlé also specifically ties its targets to the SDGs. Nestle's two largest coffee-related CSR programs are the Nescafé Plan and the Nespresso AAA Sustainable Quality Program. The former is a research and extension program for farmers intended to expand the supply of quality coffee. The latter is the company's inhouse certification standard, similar to Starbucks' C.A.F.E. program. Unlike, Starbucks, Nestlé also uses third-party certification such as FairTrade and Rainforest Alliance. Although Nestlé explicitly mentions climate adaptation in its messaging, it appears mostly limited to extensive tree planting to increase shade. This is an important adaptation strategy, but it just scratches the surface of what needs to be accomplished to promote adaptive capacity for small holder farmers.

\section{Emerging collaboration around adaptation}

Collaboration around climate adaptation in the coffee sector is piecemeal. Although the Paris Climate Agreement and the SDGs provide important frameworks and some general targets, the industry is lacking a true leader to drive adaptation research, strategy, and evaluation. However, there are some intriguing trends. First, the emergence of climate adaptation-based organizations within the past decade, such as the Global Alliance for Climate Smart Agriculture (GACSA) and FAO's EPIC Programme, highlight the growing awareness around agricultural adaptation (Newell \& Taylor, 2018). Another recent example is the Inter-American Development Bank's SAFE platform. Second, the growth of the Adaptation Fund as a legitimate source of multilateral financing over the past decade helped fill a void in climate financing specifically for adaptation, even if it pales in comparison to mitigation-based funding mechanisms. Third, the emergence and growth of the Science-Based Targets initiative could push coffee companies to base their CSR strategies on proven climate-related metrics, as opposed to more one-off programs. However, to date the initiative focuses more on mitigation targets.

\section{Discussion}

Through an analysis of the coffee industry trends and a small sampling of company profiles, I found that adaptation is mostly ignored or overshadowed by other CSR concerns. It could be argued that these companies intend to tackle adaptation concerns through improving the socio-economic status of farmers (see the "socio-economic processes" on Fig. 2). However, this seems unlikely given the rhetoric of these initiatives and the stated reasons for implementing them. Even Nestlé, which bases its CSR strategy on CSV principles, only discusses adaptation in a broad sense. What is worse is that there appears to be little sector collaboration around adaptation aside from isolated efforts. The following section explores possible explanations.

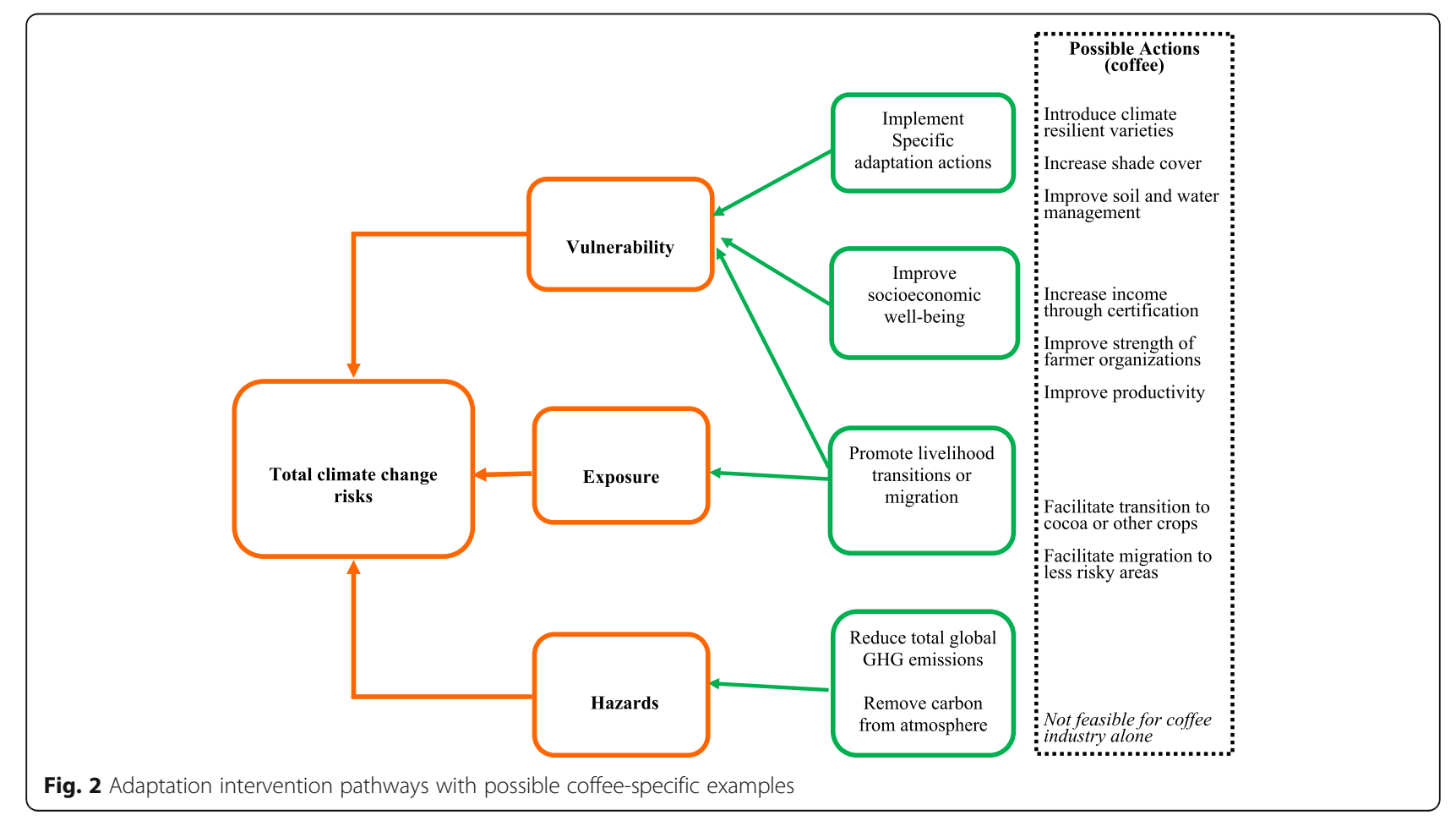




\section{Why are large coffee companies neglecting adaptation? Other CSR priorities}

All five of the companies analyzed have prominent public images. This means that they face public pressure for a range of issues beyond climate change concerns. These include, community relations, employee development and education, and reducing energy usage throughout their operations. These CSR initiatives are presumably important for the companies' stakeholders, customers, and its reputation, and may contribute to the companies' vision for CSV. It is possible that these companies understand the adaptation gap but have limited bandwidth to address them given other CSR concerns.

\section{Certification}

Coffee companies may see certification as sufficient to address climate-based concerns. All five of the companies I analyzed emphasize these standards to some extent. While in theory certification could promote climate adaptation through "socio-economic pathways", it rests on the contested assumption that certification will directly improve farmer wellbeing (see for example, Glasbergen, 2018), and that if livelihoods are improved, farmers would necessarily know which adaptation actions are needed. As problematic as this explanation is, it would corroborate some of the industry-wide criticism that too much emphasis is placed on meeting thirdparty certification standards and industry guidelines. The industry may be slow to accept climate-related initiatives outside of the certification standards and the responsible sourcing commitments they worked so long to achieve.

\section{Controversial nature of adaptation}

Another explanation is that climate adaptation may be too controversial for individual coffee companies to address. As outlined earlier, the concept of climate adaptation implies that there is no answer for climate change and that humanity must accept the impacts ("principle-based" objections). Talking about the possible extinction of coffee may be something that coffee companies want to avoid to not scare customers. For instance, Starbucks' tree donation and farmer loan programs in theory would promote adaptation, but the word "adaptation" is absent from public communications (Starbucks, 2019). Furthermore, climate change in the United States is still a highly politized topic, so US coffee companies may be reluctant to address adaptation specifically. The same way that mitigation efforts can be disguised generally as "environmental sustainability", so to can adaptation be rebranded and diluted as "livelihood development" or "poverty alleviation".

\section{Lack of awareness}

A possible but somewhat unlikely explanation is that coffee companies are not aware of the extent that the Arabica crop is threatened by climate change. While the scientific consensus is that coffee is extremely vulnerable, it may require more time and effort to disseminate this information among industry stakeholders. There is likely some lag time between new scientific evidence and implementation of related best management practices of companies because they must respond to their boards and shareholders. Still, given the technical sophistication and scientific literacy of the coffee industry, this explanation is rather weak.

\section{Lack of leadership}

It is also possible that the industry lacks clear leadership on adaptation. The original sustainable coffee movement required years and strong leadership from companies and NGOs to develop common goals, standards, and indicators. It is possible that the industry is aware of the adaptation challenge, but each company is waiting for a leader to emerge. A related concern is a lack of standardization of adaptation-based targets for the industry, a role that an industry leader could fulfill.

\section{Competition}

Related to lack of leadership is strong competition among coffee companies that deters cooperation. Companies may be reluctant to invest in adaptation since producers they invest in could easily switch buyers. There may also be hesitance to share information on techniques and best management practices to facilitate adaptation. The clean energy sector (an example of climate mitigation) faces a similar challenge with technology transfer. However, unlike the energy sector, no one owns patents on climate-smart agricultural practices, which are often promoted by NGOs and shared openly. There are some emerging trends which could potentially reduce these barriers, including the founding of the Global Coffee Platform (GGP) and the Sustainable Coffee Challenge (SCC). Both of these initiatives are non-competitive and could potentially include more adaptation specific actions if scaled-up (Panhuysen \& Pierrot, 2018).

\section{Conclusions}

Future climate impacts-even if global emission goals are met-will have deep impacts on the coffee industry. According to some estimates, the majority of current coffee growing areas will be unsuitable for its production by the end of the century (Davis et al., 2012; Laderach et al., 2017). It is clear that if the coffee industry wants to survive the next $50-100$ years, it needs to take climate adaptation more seriously. With world governments and 
donors reluctant to fund adaptation efforts due to principle and capacity/logistical reasons, one would expect major coffee companies to fill this gap. The coffee industry has a long history of CSR, making it theoretically better equipped than most industries to tackle "triple bottom line" issues. Given its CSR track record, power, and the existential threat it faces, one would expect to see major coffee companies seriously investing in adaptive practices which reduce the vulnerability of farmers. Through this approach, coffee companies could "create shared value" by simultaneously securing a steady supply of coffee and ensuring the livelihoods of farmers, their communities, and local economies.

Unfortunately, my analysis of five of the largest coffee companies did not support this assumption. These companies have expansive CSR programs, most of which include environmental or climate changed-related initiatives. Still, specific actions to reduce climate vulnerability are largely absent. Among the reasons for exclusion of adaptation activities may be competing CSR interests, limited awareness of adaptation needs, lack of leadership on adaptation, controversy around climate change as a concept, industry competition, and reliance on certification standards. This final reason deserves a more thorough analysis.

Certification programs are featured prominently by all five companies, which may serve as a stand-in for adaptation and other climate-related issues. Certification can be a powerful tool to reduce environmental impacts and create incentives for farmers. It can even reduce vulnerability to climate change by improving overall socioeconomic well-being, for example through price premiums and access to premium markets ("socio-economic pathway" to adaptation). This reasoning is problematic for two reasons. First, it assumes that farmers will necessarily improve their livelihoods significantly through meeting certification criteria. Second, it assumes that if farmers have more resources and improved livelihoods, they will automatically know what kinds of adaptive practices will reduce their future vulnerability. Certification is thus a rather roundabout way to reduce vulnerability. A more direct strategy which invests in specific adaptation actions such as introducing climate resilient varieties, increasing shade cover, improving water collection and management, and controlling climate-related pest and disease outbreaks, would more effectively reduce the vulnerability of the farmers. This strategy would be more hands-on and costly than certification, but would most directly create shared value by securing farmer livelihoods and ensuring the supply of coffee for the companies which fund it.

Climate adaptation is both a challenge and an opportunity for the coffee sector. The constraints placed on governments and private donors to meet mitigation targets, promote international development, and deal with health and security threats, make climate adaptation low on the priority list. If it wants to survive past the twenty-first century, the coffee industry cannot wait for external actors to come to the rescue. The investment needed to adapt global coffee production to a changing climate is massive and will likely surpass all previous CSR initiatives. However, it is an opportunity to reshape the industry to be more equitable and sustainable, securing profits for coffee companies and livelihoods for producers. It is also an opportunity for the industry-regarded as one of the most enlightened with regards to CSR - to position itself as a leader in adaptation and as a model for other industries struggling with the effects of climate change.

More research is needed before specific strategy recommendations can be made for the industry. Future studies will need to incorporate research from a larger number of companies and include a more rigorous analysis of individual company policies through employee and board member interviews. This primary research will be useful in understanding not only the actions of individual companies, but also perceptions of adaptation within these companies. Future research should also seek to understand the role of coffee traders in climate adaptation. Because they are less public-facing, traders were excluded from the study. However, their relative insulation from the public view may actually increase the likelihood of engaging in climate adaptation activities. Finally, additional research should also examine the appetite for more sector-wide alliances to specifically address and finance large-scale climate adaptation actions.

Although this article focused on large coffee companies, it is important to not downplay the importance of coffee farmers in the adaptation process. Adaptation is inherently a local process, and any top-down strategy which does not include those at the bottom of the pyramid is likely to be maladaptive (Sovacool, 2013). Smallholders can benefit from the dissemination of best practices and increased farmer finance. However, the global coffee industry has much to learn from smallholders, who possess generations of knowledge which allows them to make the most of limited resources in changing contexts. Creating shared value is a meaningless term without their involvement.

\footnotetext{
Abbreviations

CSR: Corporate Social Responsibility; CSV: Creating Shared Value; FAO: Food and Agriculture Organization of the United Nations; GHG: Greenhouse Gas; IPCC: Intergovernmental Panel on Climate Change; NGO: Non-governmental Organization; SGDs: Sustainable Development Goals
}

\section{Acknowledgements}

The author would like to acknowledge Professor Jette Steen Knuden, who offered feedback on the initial manuscript and encouraged publication. 


\section{Author's contributions}

I, Gino Bianco am the sole author. I conducted all research and prepared all written materials. The author(s) read and approved the final manuscript.

\section{Authors' information}

Gino Bianco is an independent researcher interested in climate adaptation, agriculture, and sustainable development.

\section{Funding}

Not applicable. No funding from any source.

\section{Availability of data and materials}

Not applicable.

\section{Competing interests}

No competing interests to declare.

\section{Received: 6 May 2020 Accepted: 20 July 2020}

Published online: 12 August 2020

\section{References}

Austin, J. E., \& Reavis, C. (2004). HBS 9-303-055, "Starbucks and Conservation International". Cambridge: Harvard Business School.

Bansal, P., \& Roth, K. (2000). Why companies go green: A model of ecological responsiveness. (factors to ecological corporate motivation) (critical essay). Academy of Management Journal, 43(4), 737. https://doi.org/10.2307/1556363.

Barkemeyer, R. (2011). Corporate perceptions of sustainability challenges in developed and developing countries: Constituting a CSR divide? Social Responsibility Journal, 7(2), 257-281. https://doi.org/10.1108/ 17471111111141521

Bradley, O. J., \& Botchway, G. O. (2018). Communicating corporate social responsibility (CSR) in the coffee industry: An examination of indicators disclosed. Sustainability Accounting, Management and Policy Journal, 9(2), 139-164. https://doi.org/10.1108/SAMPJ-02-2017-0015.

Brown, D., \& Knudsen, J. (2012). Managing corporate responsibility globally and locally: Lessons from a CR leader. Business and Politics (Berkeley), 14(3), 1-29. https://doi.org/10.1515/bap-2012-0021.

Buchner, B. K., Padraig, O., Wang, X., Carswell, C., Meattle, C., \& Mazza, F. (2017). Global landscapes of climate finance 2017. In Climate Policy Initiative.

Business Dictionary "Corporate Social Responsibility". Retrieved from http://www. businessdictionary.com/definition/corporate-social-responsibility.html. Accessed 1 Apr 2019.

Campbell, J. (2007). Why would corporations behave in socially responsible ways? An institutional theory of corporate social responsibility. Academy of Management Review, 32(3), 946-967. https://doi.org/10.5465/AMR.2007. 25275684 .

Carroll, A. B. (2001). Corporate social responsibility: Evolution of a definitional construct. Business \& Society 38(3), 268-295

Carroll, A. B. (2016). Carroll's pyramid of CSR: Taking another look. International Journal of Corporate Social Responsibility, 1(1). https://doi.org/10.1186/s40991016-0004-6.

Cohn, A. S., Newton, P., Gil, J. D. B., Kuhl, L., Samberg, L., Ricciardi, V., ... Northrop, S. (2017). Smallholder agriculture and climate change. Annual Review of Environment and Resources, 42, 347-375. https://doi.org/10.1146/annurevenviron-102016-060946.

Crane, A., Palazzo, G., Spence, L. J., \& Matten, D. (2014). Contesting the value of "creating shared value". California Management Review, 56(2), 130-153. https://doi.org/10.1525/cmr.2014.56.2.130

Daviron, B. and Ponte, S. (2005). The coffee paradox: global markets, commodity trade, and the elusive promise of development. London; New York New York: Zed Books in association with the CTA; Distributed in the USA by Palgrave Macmillan.

Davis, A. P., Gole, T. W., Baena, S., \& Moat, J. (2012). The impact of climate change on indigenous Arabica coffee (Coffea arabica): Predicting future trends and identifying priorities (climate change and indigenous Arabica coffee). PLOS ONE, 7(11), e47981. https://doi.org/10.1371/journal.pone.0047981.

Dunkin' Donuts, (2017). 2015-2016 Corporate Social Responsibility Report.

Escobar Botero, M., Arboleda Diaz, A. M., Marín Cadavid, C., \& Muhss, M. (2011). CSR practices in the coffee industry: A preliminary review of Kraft Foods, Nestlé and Starbucks. Revista de Negocios Internacionales, 4(2), 30-44.
FAO (2015a). FAO statistical pocketbook: Coffee. In. Rome: Food and Agricultural Organization of the United Nations.

FAO (2015b). The impact of natural hazards and disasters on agriculture, food security and nutrition. In. Rome: FAO.

Glasbergen, P. (2018). Smallholders do not eat certificates. Ecological Economics, 147, 243-252. https://doi.org/10.1016/..ecolecon.2018.01.023.

Hamann, L., Luschnat, K., Niemuth, S., Smolarz, P., \& Golombek, S. (2014). CSR in the coffee industry: Sustainability issues at Nestlé-Nespresso and Starbucks. The Journal of European Management and Public Affairs Studies, 2(1). https:// doi.org/10.15771/2199-1618_2014_2_1_5.

Idemudia, U. (2014). Corporate social responsibility and development in Africa: Issues and possibilities. Geography Compass, 8(7), 421-435. https://doi.org/10. $1111 /$ gec 3.12143

IPCC (2014). Climate change 2007: Impacts, Adaptation and Vulnerability. Summary for policy makers. https://doi.org/10.2134/jeq2008.0015br.

Klein, R. J. T., Schipper, E. L. F., \& Dessai, S. (2005). Integrating mitigation and adaptation into climate and development policy: Three research questions. Environmental Science and Policy, 8(6), 579-588. https://doi.org/10.1016/j. envsci.2005.06.010.

Kolk, A. (2005). Corporate social responsibility in the Coffee Sector:: The Dynamics of MNC responses and code development. European Management Journal, 23(2), 228-236. https://doi.org/10.1016/j.emj.2005.02.003.

Kolk, A. (2011). Mainstreaming sustainable coffee. Sustainable Development, 21(5). https://doi.org/10.1002/sd.507.

Laderach, P., Ramirez--Villegas, J., Navarro-Racines, C., Zelaya, C., Martinez-Valle, A. \& Jarvis, A. (2017). Climate change adaptation of coffee production in space and time.(report). Climatic Change, 141(1), 47. https://doi.org/10.1007/s10584016-1788-9.

Latapi Agudelo, M. A., Johannsdottir, L., \& Davidsdottir, B. (2019). A literature review of the history and evolution of corporate social responsibility. (review article)(report). International Journal of Corporate Social Responsibility, 4(1). https://doi.org/10.1186/s40991-018-0039-y.

Lecocq, F., Hallegatte, S., \& De Perthuis, C. (2011). Designing Climate Change Adaptation Policies: An Economic Framework. IDEAS Working Paper Series from RePEC.

Levy, D., Reinecke, J., \& Manning, S. (2016). The political dynamics of sustainable coffee: Contested value regimes and the transformation of sustainability. Journal of Management Studies, 53(3), 364-401. https://doi.org/10.1111/joms. 12144.

Lyster, R. (2017). Climate justice, adaptation and the Paris Agreement: A recipe for disasters? Environmental Politics, 26(3), 438-458. https://doi.org/10.1080/ 09644016.2017 .1287626

Micale, V., Tonkonogy, B., \& Mazza, F. (2018). Understanding and increasing finance for climate adaptation in developing countries. In Climate policy initiative and Adelphi.

Millard, E. (2017). Still brewing: Fostering sustainable coffee production. World Development Perspectives, 7-8, 32-42. https://doi.org/10.1016/j.wdp.2017.11. 004.

Nelson, D. R. (2011). Adaptation and resilience: Responding to a changing climate. Wiley Interdisciplinary Reviews: Climate Change, 2(1), 113-120. https:// doi.org/10.1002/wcc.91

Nestlé. (2018). Nestlé in society: creating shared value and meeting our commitments 2017.

Newell, P., \& Taylor, O. (2018). Contested landscapes: The global political economy of climate-smart agriculture. The Journal of Peasant Studies, 45(1), 108-129. https://doi.org/10.1080/03066150.2017.1324426.

OECD (2012). Integrating climate change adaptation into development co-operation : Policy guidance. Paris: OECD.

Ostrander, M. (2013). Adapting to climate change: It's not about giving up, it's about getting real. YES Magazine Online https://www.yesmagazine.org/ environment/2013/11/02/adapting-to-climate-change-it-s-not-about-givingup-it-s-about-getting-real/. Accessed 1 Apr 2019.

Ostrom, E. (2008). A Polycentric Approach For Coping With Climate Change. IDEAS Working Paper Series from RePEc.

Panhuysen, S., \& Pierrot, J. (2018). Coffee barometer 2018. The Hague: Hivos.

Porter, M. E. \& Kramer, M.R., (2011). Creating shared value. Harvard business review: HBR, 89(1), 62-77.

Ragodoo, N. J. F. (2009). CSR as a tool to fight against poverty: The case of Mauritius. Social Responsibility Journal, 5(1), 19-33. https://doi.org/10.1108/ 17471110910939971.

Rahn, E., Vaast, P., Läderach, P., van Asten, P., Jassogne, L., \& Ghazoul, J. (2018). Exploring adaptation strategies of coffee production to climate change using 
a process-based model. Ecological Modelling, 371, 76-89. https://doi.org/10. 1016/j.ecolmodel.2018.01.009.

Samper, L., \& Quiñones-Ruiz, X. (2017). Towards a balanced sustainability vision for the coffee industry. Resources, 6(2), 17. https://doi.org/10.3390/resources6020017.

Sovacool, B. (2013). Adaptation: The complexity of climate justice. Nature Climate Change, 3(11), 959. https://doi.org/10.1038/nclimate2037.

Stanton, E. (2011). The social cost of carbon. Environmental Forum, 28(6), 38-41.

Starbucks. (2018). Global Social Impact: 2017 Performance Report.

Starbucks. (2019). Investing in Coffee Communities. Retrieved from https:/www. starbucks.com/responsibility/community/farmer-support/social-developmentinvestments. Accessed 20 Apr 2020.

Talbot, J. M. (2004). Grounds for agreement: The political economy of the coffee commodity chain. Lanham: Rowman \& Littlefield Publishers.

Tchibo. (2018). Corporate responsibility. https://www.tchibo.com/servlet/content/ 893154/-/en/corporate-responsibility.html. Accessed 1 Apr 2019.

The Economist Business Unit (February 2008). Doing good: Business and the sustainability challenge. The Economist, 1, 31-38.

The European Commission Corporate Social Responsibility \& Responsible Business Conduct. In Internal Market, Industry, Entrepreneurship and SMEs Retrieved from https://ec.europa.eu/growth/industry/sustainability/corporatesocial-responsibility_en. Accessed 1 Apr 2019.

The Paris Agreement (2016). United Nation United Nations Treaty Collection.

The White House Office of the Press Secretary (2015). FACT SHEET: White House Announces Commitments to the American Business Act on Climate Pledge [Press release]. Retrieved from https://obamawhitehouse.archives.gov/thepress-office/2015/10/19/fact-sheet-white-house-announces-commitmentsamerican-business-act. Accessed 15 Apr 2020.

Tim Horton's (2015). Sustainability and Responsibility: 2014 Performance Highlights.

Visser, W. (2009). Corporate social responsibility in developing countries. The Oxford Handbook of Corporate Social Responsibility. https:/doi.org/10.1093/ oxfordhb/9780199211593.003.0021.

Wood, M. (2019). Climate adaptation Isn't surrender. It's Survival. Ideas. Retrieved from https:/www.wired.com/story/climate-adaptation-isnt-surrender-itssurvival/. Accessed 15 Apr 2020

\section{Publisher's Note}

Springer Nature remains neutral with regard to jurisdictional claims in published maps and institutional affiliations.

\section{Submit your manuscript to a SpringerOpen ${ }^{\circ}$ journal and benefit from:}

- Convenient online submission

- Rigorous peer review

- Open access: articles freely available online

High visibility within the field

- Retaining the copyright to your article

Submit your next manuscript at $\boldsymbol{\nabla}$ springeropen.com 